\title{
SOCIOLOGICAL THEORY IN GEOGRAPHY: PHASE OF EMPIRICAL-ANALYTICAL SCIENCE
}

DOI: https://doi.org/10.18509/GBP210575m

UDC: 316.2:911]:303.025

911.3:30

\section{Goran Mutabdžija}

University of East Sarajevo, Faculty of Philosophy, Pale, Bosnia and Herzegovina

\begin{abstract}
For the initial phase of the development of modern geography, in addition to its philosophical foundations in the post-Hegelian period, social theory was also of great importance. Its ancestor in the first half of the XIX century. was A. Comte (1798 - 1857), and crucial importance was given to it by the most important representatives of "grand theories": classical theories, contemporary theories, and contemporary theories of everyday life. The historiographical-methodological aspect of the development of sociological theory is provided by sociologists ([42], [44]), while the influence of sociological theory on geography presented by numerous geographers ([6], [10], [16]). The subject of this paper refers to the first phase in the development of geographical science during modern times, during which it had the character of empirical - analytical science ([18], [51]). During this period, numerous directions developed within social geography, which are best represented by the concepts of natural determinism, regional tradition, cultural determination and quantitative revolution, and which are partially united by the concepts of geography as a spatial science ([7], [23] [29], [39]) or positivist geography ([3], [25]). During this period, the works of A. Humboldt and C. Ritter represented the starting point for the development of the first phase of scientific geography (anthropological), the subject of which was the relationship between man and nature [28]. This was best demonstrated through the concept of Lebensraum [41], as a synthesis between biogeography and anthropogeography. At the same time, some other concepts, such as the ideas of P. Kropotkin and E. Reclus, will take a century to revive (radical geographies). During the second phase (first decade of the XX century), the subject of studying geography moved towards the region and the laws of its formation, and on the premises of different concepts as possibilism, chorologism and exceptionalism ([21], [52], [56]). The strong penetration of new elements of social theory (cultural contents) into the geographical studies of the region confirms the landscape as a new subject of research, which is embedded in the development of cultural geography [46]. Finally, the application of the principles of logical positivism leads to a quantitative revolution in geography ([4], [36], [54]).
\end{abstract}

Keywords: geography of modernity, social theory, empirical-analytical science, positivism.

\section{INTRODUCTION}

Modern is a period in the development of modern scientific thought that has a different duration in the social sciences. Weber (1989) linked the emergence of modernism to "Occidental rationalism" (the West), whose economic prosperity (capitalism) was crucially contributed by the ethics of Protestantism. Before defining the doctrinal issues 
of modernity, Habermas [17] classified scientific knowledge, ie. science and phase in their development on: empirical-analytical (technical interest), historical-hermeneutic (practical interest) and critical-dialectically oriented sciences (emancipatory interest). Then, he [18] defined the notion of modernity as a set of cumulative and mutually reinforcing processes, such as: capital creation and resource mobilization; development of productive forces and increase of labor productivity; affirmation of central political forces and shaping of national identities; expansion of political rights participation, urban life forms, formal school education; secularization of values and norms, etc. He also claims that:

After Hegel's death, the paths of school and secular philosophy separated again. School philosophy must compete with private assistant professors, writers and private individuals such as Feuerbach, Ruge, Marx, Bauer, Kierkegaard - and one Nietzsche, who left the Basel professorship. Within the university, the task of theoretical selfunderstanding of modernity is ceded to state and social sciences, as well as ethnology. In addition, names such as Darwin and Freud, trends such as positivism, historicism and pragmatism confirm the fact that in the nineteenth century. physics, psychology, and the historical sciences liberate worldview motives, which for the first time, without the mediation of philosophy, influence the consciousness of time [18].

It is certain that for Habermas modernity ${ }^{16}$ begins at the end of the 18 th century, while its end is an open question. On the one hand, he suggests that postmodernism is already beginning with Nietzsche, that is, "that against discourse, which from the beginning resides in this philosophical discourse of modernity, it began with Kant and thus created the opposite of subjectivity as a principle of modernity" (Ibidem, 278). On the other hand, he suspects that the modern is an "unfinished project" that has not yet been fully realized. That is why he states that the radical critique of the mind has led to the abandonment of modernity, and that negative dialectics ${ }^{17}$, deconstruction ${ }^{18}$, and genealogy cannot be unambiguously included in philosophy or science, or in the theory of morals and law, or in literature and art." the epoch of modernity is connected with the non-dialectical rejection of the principle of subjectivity.

It is clear from this that the issues of theoretical development of geography must be viewed far beyond the narrow philosophical framework, primarily through the influence of social theory, and thus the question of the duration of modernity needs to be defined more precisely. The beginning of the development of modern geographical thought can be roughly determined as the middle of the 19th century, and the end of the second half of the 20th century. The appearance of the first scientific geographical societies (Royal geographical society, London 1830) or regular geographical classes at all universities in Germany ${ }^{19}$ can be considered as indicative events. Taylor (1985) notes that C. Ritter in Berlin (1820) briefly established a course in geography, and that the first permanent

\footnotetext{
${ }^{16}$ He probably does not mean a specific event, but the processes that Hegel spoke about, which have expanded sufficiently over most of Europe and created the preconditions for the beginning of a new era.

${ }^{17}$ It refers to the "negative turn" that Adorno and Horkheimer made in the Dialectic of the Enlightenment.

${ }^{18}$ This term represents Derrida's departure from structuralism, by which he explores the sedimented structures that shape the philosophical discursiveness within which we think, and one of his most famous works is Grammar.

${ }^{19}$ After the victory over the French in 1871, Bismarck understood the importance of geography, so he introduced it by decree to all German universities.
} 
courses were established in Wien (1851) and Giessen (1864). Peet (1998), in his desire to more precisely define this time frame, begins the modern connection with the year of death (1859) of the first scientific geographers (A. Humboldt and C. Ritter), and connects the end with the emergence of neoliberalism in the late 1970s. Also, in theoretical terms, he focuses on geographical directions that developed in the second half of the twentieth century, from existentialism, phenomenology, humanistic, radical, Marxist geography, etc. Most other modern geographers avoid more precise dating of this period, e.g., Johnston (1997), who is indispensable in assessing and periodizing the development of geographical science and who, according to Agnew (1989), identifies a series of "paradigms or philosophies and methods" in which the history of geographical ideas is successfully presented. He emphasizes the adoption of the scientific method in geography, the development of spatial analysis and spatial science, and various concepts within behavioral, humanistic and radical geography. He does not emphasize the conditional boundary between the period of modern and postmodern time, but it is discreetly read through the description of the cultural turn in geography in the late 1980s, which is characterized by the emergence of new directions (feminism; identity politics; the question of language and discourse; reinterpretation of the old).

The late 1980s saw changes within human geography which were both reactions to preceding disciplinary development and responses to external approaches and no longer considered them viable, especially those associated with spatial science, although some continued to explore large data sets in the mold established by behavioral geographers: locational science was a small, relatively isolated sub-set of active geographers, and development in GIS did not make a substantial impressions on much of the discipline, indeed, many were very critical [23].

Other important historians of the theoretical and methodological development of modern geography maintain a similar approach. One emphasizes the result of a critique of the positivist approach or the development of geography as a spatial science, which crystallized in two directions in the late 1960s as radical and as humanistic approaches [7]. Another one embraced a far broader time frame and emphasized the plurality of geographical thought that carries the inevitability that we must live with positivist, Marxist, humanistic, Islamic, structuralist, Christian, folk geography, etc. [29]. The third introduces a clearer division within the modern development of geographical thought, based on Habermas' (1975) classification of scientific knowledge [50].

Table 1: Habermas's theory of cognitive interests

\begin{tabular}{llll}
\hline Form of science & $\begin{array}{l}\text { Knowledge- } \\
\text { constitutive interest }\end{array}$ & $\begin{array}{l}\text { Social } \\
\text { medium }\end{array}$ & Expression trough \\
\hline $\begin{array}{l}\text { Empirical- } \\
\text { analytic }\end{array}$ & Technical & Work & Material production \\
\hline $\begin{array}{l}\text { Historical- } \\
\text { hermeneutic }\end{array}$ & Practical & Language & Communication \\
\hline Critical & Emancipatory & Power & Relations of domination and constraint \\
\hline
\end{tabular}

Source: Unwin, 1992: 30

Based on this, we can now narrow down our subject of research and focus on the development of scientific geography in the modern period with precise timing. For us, the beginning of this period begins with the organization of university geographical teaching in Europe, and ends with the appearance of capital philosophical-geographical achievements (Harvey, Explanation in geography; Lefebvre, La Production de l'Espace). 
In this way, within this incomplete lifespan (spatial and empirical-analytical science) we get a precise temporal (1874 - 1969) and theoretical-methodological framework (anthropological, regional, cultural and quantitative geography) of this research. In this way, the extensive works of researchers from the period 1960 - 1980, which methodologically fit into behavioral geography, and humanistic and radical approaches, because they belong to the historical-hermeneutic science, are excluded.

The complexity of historical-geographical and scientific-methodological development of geographical thinking during the modern period requires a certain degree of generalization and visualization of concepts, processes and researchers in a given time frame. Therefore, we will accept the challenge to present this scientific cognitive process on the basis of reference literature in the form of a multilayer diagram in which the first level represents the type of science [17], the second refers to dominant paradigms [23], and the presentation of other layers, disciplines, methods, key thinkers) is the result of the author 's reflection on the subject of the paper. In order to clarify the following diagram, it is important to mention that most of the cited sources in the paper refer to Anglo-Saxon geography, for which regional geography begins with Hartshorne [21

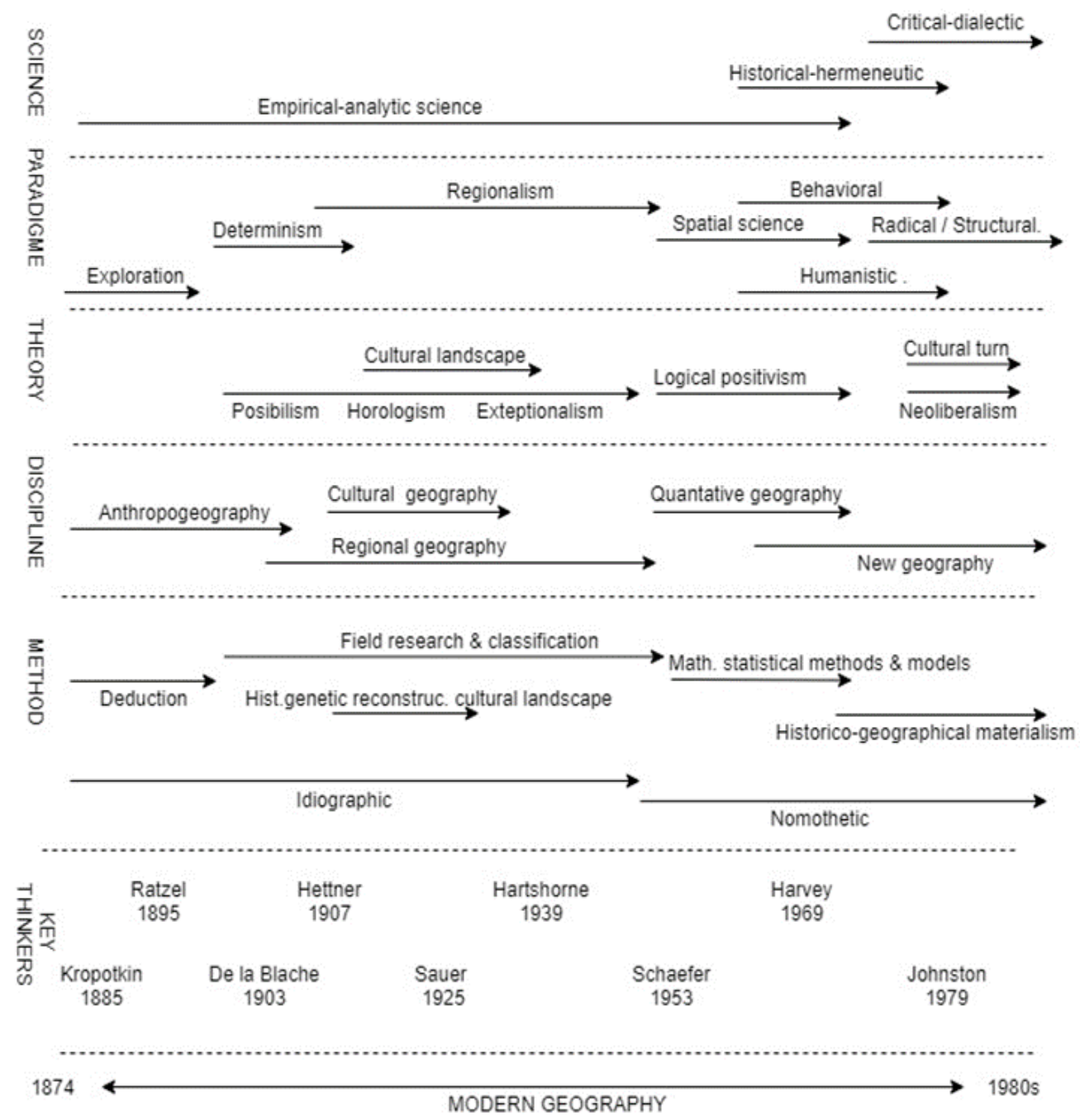

Diagram 1: Scientific and paradigmatic development of geographical thinking in the modern period 
Nevertheless, the same author had previously translated Hettner's major work Characteristics of Regional Geography into English ${ }^{20}$, making Hettner not only the most important German geographer in the early stages of modern geography, but also a widely influential one [56]. Development of regional geography moved to the first decade of the 20th century in which the capital works of De la Blache (Tableau de la Geographie de la France, 1903) and Hettner (Grundzüge der länderkunde, 1907) were published. Considering the year of the beginning of regular geographical teaching at universities, anthropogeography ${ }^{21}$ was included in this period, as an early modern geographical school, which was a good connection with the 20th century. and the dynamic development of scientific geography.

In this way, on the geographical side, we made an introduction to what the term geographical imagination is, and it was introduced into wider use by D. Harvey, who tried to relate to what sociologist W. Mills had previously identified as sociological imagination. According to Gregory (1994: 81 - 82), both authors sharply criticized the prevailing orthodoxy in geography and sociology, which emphasized ethical and political responsibility in clarifying the links between the terms place and space (Harvey, 1973), respectively biography and history (Mills, 1959). It is clear that social geography until then, for the most part, showed little interest in social processes, while sociology paid little attention to theorizing the spatiality of social life. Only now can we begin a historical-geographical description of the origin and development of social theory, the crown stone ${ }^{22}$ in the construction of the four-sided pyramid (geography, philosophy, social theory and political economy) of social geography in the first modern period, which had the character of empirical-analytical science.

\section{The emergence of Social theory}

The name sociology, as well as its basic theoretical postulates, is considered to be the result of the scientific work of A. Comte, whose capital work included the Cours de philosophie positive (1830 - 1842) and Système de politique positive (1848 - 1854). He not only gave a name to sociology (1839), explained the transition of primitive societies into modern ones (theological, metaphysical and positivist phase), but also established a positivist direction that would strongly determine the character of social sciences and humanities and which, with certain amendments (logical positivism 1920s - 1930s), to be dominant until the middle of the 20th century (in social geography 1953 - 1969). Sociology is defined as the science of society, to which Comte's successors gave a deeper meaning, while social theory is a narrower term, which arises from the self-conscious speculation of social theorists about social reality and social relations.

It can be concluded that they, like other scientists, rely on the results of their predecessors, explaining social reality through databases, on the basis of which they base their own theories on a wide range of social problems [43]. Only those theories that stand the test of time, and at the same time have a wide scope of application, become generally accepted. That is why sociological theory is defined as "a set of interconnected ideas that

\footnotetext{
${ }^{20}$ He received the Cullum Award in 1930, the highest recognition of the American Geographical Society

${ }^{21}$ Ruppert et. al. state that the development of this direction went through four phases: geodeterministic (La Play and Ratzel), possibilistic (P. V. d. 1. Blache), morphogenetic (Durkheim and Schluter) and functional (Park, Burgess, Bobek, Christaller).

22 The name for the final stone in the circular roof structure, about whose examples and symbolic meaning, see: G. Mutabdzija, Geophilosophy of the premodern, Amazon (2021).
} 
enable the systematization of knowledge about a society, the explanation of that society and the prediction of its future" [41]. As space, place, and landscape, as central subjects in the study of social geography, have become interesting for the humanities and social sciences, the broader implications of the contemporary permeation of social theory and geography are most evident in political ecology and cultural policy of nature [9]. These have become, probably, the most important issues which, by their nature, have significant implications for the main social theory, in which the notions of power, knowledge and space are recognized. This is somewhat confirmed by the characteristic geographical interpretation of the concept of social theory:

I do not use it as a synonym for sociology or even social science. Instead, I propose to treat social theory as a series of overlapping, contending and contradictory discourses that seek, in various ways and for various purposes, to reflect explicitly and more or less systematically on the constitution of social life, to make social practices intelligible and to intervene in their conduct and consequences [16].

However, the modern interpretation of sociological theory abandons the idealized conditions in which it arises and suggests that it is similar to society, that is. to be influenced by a wide range of political factors. It can recognize the crucial role in emphasizing the importance of certain theories through relationships political forces in society, and: the importance of mentoring that current theorists have gone through, dominant political orientations in society, empirical verifiability of the hypotheses on which these theories are based, as well as the affiliation of their authors to dominant and influential social groups [41]. It is clear that this affiliation has a variable geographical definition, depending on the political-geographical and cultural matrix of individual countries or regions. Therefore, only a few theories reach a certain level of universal acceptability, as an expression of their scientific orthodoxy or canon.

Within these theories, we distinguish three types. The former is defined as grand theories, which deal with social structures and significant social changes, and therefore represent the interpretation of large time segments of human history and / or large parts of society. This term can also be used to denote all theories that successfully describe the transition from one type of society to another (primitive - modern, feudal - capitalist, production - consumer). The second type are theories of everyday life, which focus on everyday problems of small scale, they are also called theories of everyday life, and therefore represent the opposite of grand - theories. The third type refers to theories that try to integrate the previous two types. Given the time of their creation, the subject of our interest are classical theories I (1870 - 1920) and modern theories of everyday life (1930 - 1970s).

The classical age of sociology encompasses the late nineteenth and early 20th centuries and refers to theories created by the first generation of sociologists, primarily Emil Durkheim, Carl Marx, and Max Weber. These founders of the most important grand theories are joined by Georg Simmel, Thorstein Veblen and George Mead. 
Table 1: Overview of the most significant authors of grand theories in the classical period

\begin{tabular}{lll}
\hline Key thinkers & The theory is significant for explanation & Key concept \\
\hline E. Durkheim & The transition from primitive to modern society & Social facts \\
\hline C. Marx & The Proletariat and the Enrichment of the Capitalists & Exploitation \\
\hline M. Weber & Rationalization of the West through social action & Bureaucracy \\
\hline Simmel & The tragedy of culture and the theory of everyday life & Mystery and space \\
\hline T. Veblen & Conflict between business and industry & Consumption and leisure \\
\hline G. Mead & Sociology of Everyday Life & Definition of the situation \\
\hline
\end{tabular}

Given the subject of study and key concepts in their grand theories, the works of Durkheim and Weber are important for the empirical-analytical phase of geography, while the grand theories developed by the other four authors (Marx, Simmel, Veblen and Mead) relate to theories. Marxism, everyday life and consumption, which in the sphere of geographical interest (epistemological aspect) belong to the historical - hermeneutic phase of geographical science, so it will not be the subject of this paper.

\section{Durkheim and Vidal: from social morphology to possibilism}

Emil Durkheim (1858 - 1917) is considered a successor to Comte's work, which surpassed his teacher. This is reflected in the successful theoretical development of sociology, but also in the establishment of a specific way of thinking, which has left a significant mark on most contemporary sociology theorists. His capital contribution to sociology is reflected in the establishment of a theory, which through the terms: solidarity (concerns diversity based on the contribution of a large number of members of society), dynamic density (represents the number of people and frequency of their interaction) and collective consciousness (beliefs and feelings common to members of a group, tribe or society) explained the historical transformation of primitive mechanical societies (eg hunting gathering economy was characterized by mechanical solidarity or absence of division of labor, in which everyone did everything ) in modern organic societies (occur in societies with a developed division of labor and specialization of craft and other jobs). He had a great influence, not only on sociology (he is considered its founder), but also on anthropography, which focuses on three main types of problems: the description of ethnographic facts; inductive reconstruction of long-term cultural history; and the development of general propositions about culturally regulated human behavior [26]. This was transferred to the then dominant anthropogeographic school [28].

Also, his contribution to geography was achieved through a kind of rivalry with Paul Vidal de la Blache, who is considered the founder of social geography. Although Vidal was 13 years older, their scientific careers were almost identical, and they both died almost simultaneously. While Durkheim was born into a Jewish family in the east of France (Espinal, Vosges), Vidal came from a conservative Catholic family from the south, who was educated in Avignon. In that period, elite education was not reserved only for the best students, which they both certainly were, but a certain hereditary social status was also necessary. The Durkheimian were rabbis, while Vidal's father was a high school teacher and his grandfather a customs officer. This is best confirmed by the commentary on the historical circumstances in France at that time, according to which "a peasant could still expect his son to become a teacher, and he to get his son to become a teacher in high school, while only his son could become a university professor and member of the Institute" [52].

After primary education in local communities, Durkheim and Vidal were educated in Paris. While Vidal came to the Favard institution at the age of 13 and then to the Lyceum 
of Charlemagne, at the age of 18 Durkheim enrolled at the Jauffret institution and then at the Luis-le Grande lyceum [1]. This was just a preparation for the prestigious Ecole Nationale Superieure (ENS) whose students become, Vidal after the second attempt at the age of 18, and Durkheim after the third attempt at the age of 21. After three years of study, they both successfully passed the aggregation exam, Vidal as the first in the history-geography group, and Durkheim as the seventh in the philosophy group. After this, they both worked in high schools, Vidal in Carcason, and Durkheim in several provincial schools (Puy, Sans and Saint Quentin), after which they continued their postgraduate studies. Vidal at the Ecole francaise d'Athenes, and Durkheim received an international scholarship to stay in Berlin, Leipzig and Marburg.

The careers of university professors of crayons began early, Vidal at the age of 26 as an assistant professor (maitre de conferences) in Bordeaux, and Durkheim at the age of 29 in Nantes. After this experience, Vidal spent twelve years at ENS, and then the same number at the Sorbonne, as head of the geography department. Durkheim spent fifteen years in Bordeaux before crossing the Sorbonne. Their followers are dubbed Durkheimian and Vidalians, their followers were called Durkheimian and Vidalians, and were constantly interacting on three different sets of research questions. The first relates to the growing interest in modern history (geography, sociology, and the social sciences), especially about how these different interests came together as institutionalized disciplines in France and Europe in the late 19th and early 20th centuries. The second set of questions emphasizes the existence of an extensive literature on the history of ideas and the history of geographical and sociological thought, while the third refers to the connections between Durkheimian and Vidalians, and seeks a conceptual foundation for social geography and revived humanistic geography [1].

Despite the similarities in individual careers, their political and scientific orientations were significantly different. Durkheim and his supporters (Durkheimian) were proponents of positivism, rationalism or realism, leftist views and socialism, who published papers on social morphology in the journal Annee sociologique (Mauss, Halbvachs, Simiand and Hubert). At the same time, Vidal and his like-minded people (Vidalians) pinned their hopes on neo-Kantianism or nominalism, liberal or moderately conservative beliefs, wrote for the Annales de Geographie, and shaped their views within possibilism ${ }^{23}$ as a regional geographic direction. The interpretation of the basic contextual settings of this geographical school is most comprehensively presented in Vidal's fifth book The Physiogamy of France (Tableau de la géographie de la France, 1903), followed by regional monographs, which were doctoral theses under Vidal's mentorship: Demangeon (1905), Blanchard (1906), Vallauk (1907), Vacher (1908) and Zion (1909). These regional monographs soon became a model for studying regional geographic content at universities around the world. In addition to these narrowly geographical themes, Vidalians have contributed significantly, in theoretical terms, to the understanding of the concept of place and influenced on historians of the Annales School of History [5]. Although Tableau was an introduction to a much larger project ${ }^{24}$, outside the narrow geographical framework, which focused on French natural history and longterm social and cultural development, it was challenged by the Durkheimian because it did not articulate laws but pointed to coincidences and ambiguities between nature and society. A kind of mirror in the relations between these two groups of French scientists,

\footnotetext{
${ }^{23}$ See: G. Mutabdzija, Regional geography of Europe

${ }^{24}$ Ernest Lavisse, Histoire de France, a 27 -volume edition covering the period before the 1789 revolution.
} 
he represented their critical attitude towards the works of the German geographer F. Ratzel ${ }^{25}$, whose works Vidal read and commented on meticulously.

While Ratzel moved from the life sciences into geography, Vidal was originally a historian and therefore less inclined to emphasize the physical constraints than the historical experience of those who populated and thus formed a region. Vidal's effort to build a respectable geographical discipline occurred in the political context of the defeat of France in 1871 and the loss of the Alsace region. His regional motive was embedded in a political battle concerning a better administrative practice in France. His historical inclination imbued his geography with a 'cultural turn' that conditioned a lot of work in this vein during the 20th century [48].

In addition to this political-geographical reason, the essence of Ratzel's critique referred to natural determinism, a widely present paradigmatic approach in the geography of that period, where Durkheim was initially helped by Ratzel's work in specifying the nature of social morphology and strengthening the view of sociology and human geography. On the other hand, Vidalians Ratzel's writings helped to diminish the influence of determinism in social geography, especially emphasizing the interaction between human activity and the physical environment, mediated through the relations of animate and inanimate nature. French possibilism would serve C. Sauer, along with the foundations of the German Landschaft School ${ }^{26}$ and American anthropologists from the Berkley School (Kroeber and Lowie), to constitute cultural geography as a new discipline that would dominate the United States until the early 1950s. Her focus was also on the role of religion, which contributed to the transformation (superorganic construction) of the cultural landscape. It was the processes through which religion influences the landscape are not much studied, but the focus was on the spatial distribution of these landscapes [13]. The importance of religion, as a factor in reshaping the landscape, was also contributed by the ideas of Max Weber, which will temporarily strengthen ecological determinism. Cultural geography will lose its original significance in the early 1950s, as it will be characterized as "too descriptive, atheistic and apolitical" [36].

\section{The Weber brothers: rationalization, social action, and the location of industry}

In the history of modern science, there are rare examples of brothers who have achieved top scientific results in various scientific fields. Such an example is provided by the brothers Weber, Max (1864 - 1920) and Alfred (1868 - 1958). Both had a broad academic education, with Max studying law in Heidelberg and then history and law in Berlin. He earned a doctorate in the history of labor law, after which he began his academic career at the University of Freiburg and then in Heidelberg. The focus of his interest shifted from teaching to social issues, and the culmination of his scientific contribution was in the field of sociology, which he defined as a science that "wants to understand and interpret social action and thus explain what is causal in its course and its consequences." [43].

\footnotetext{
${ }^{25}$ Anthropogeographie I -II (1881, 1891), Politische Geographie (1897), Völkerkunde (1885 -1888), and is best known for the concept of lebensraum (living space) through which he explained Germany's expansionist ambitions in terms of a Darwinian struggle for survival, a which the Nazis abused in a geostrategic sense.

${ }^{26}$ Created as a reaction to natural determinism developed by Ritter and Ratzel, the most important representatives were: Hettner, Schlüter, Passarge and Krebs.
} 
This definition of Max derives from his rich theoretical work (theory of social action and theory of rationalization), which includes a diverse and complex conceptual apparatus. His work has left a big mark in the social sciences, and the starting point in the theory of social action is the distinction between the concepts of behavior and action. The first term refers mainly to unconscious actions that occur without conscious thinking and is closely related to the eponymous psychological concept (behaviorism), which significantly influenced the emergence of sociological theories of everyday life. The second term refers to conscious human actions, which Weber classifies into: affective, traditional, value rational and goal - rational action. Because of this, the notion of action was the core of his interest and meant that a thought process took place between "stimulus and reaction to stimulus", so for him these were situations in which people attached meaning to their actions. According to him, understanding is a key methodological technique through which the researcher tries to understand the thought process of actors, its meanings and motives, as well as how they affect the action being studied.

Weber's second theory has a broader meaning and relates to the rationalization ${ }^{27}$ he explained in his major work [53]. As can be seen from the title, he recognized the great influence of the ethics of different religions ${ }^{28}$ in the development of capitalism. Among Calvinists, this influence is based on eschatology (predestination), which considers success in business as the main sign of choice (paradise). Therefore, this belief contributed to the formation of moral qualities in workers and entrepreneurs (thrift, diligence, punctuality, honesty, the pursuit of money), which significantly improved the spirit of capitalism, based on the motive to achieve success as an expression of moral norms, not greed. Related to this is the structure of government that has different legitimacy (tradition, charisma and legality) and which, depending on the degree of rationalization, develops in the direction of traditional, charismatic or rational - legal. Weber emphasizes the concept of the ideal type, as a unit of measurement for comparing examples of different social phenomena, and cites bureaucracy ${ }^{29}$ as the most successful example. Related to this is his interpretation of the notion of territory, as the idea of a limited space under the control of a group or state, which is called Weber's phrase. He opposes the idea that the ruler has a monopoly on power (legitimate physical violence), because the borders of the territory are in no way fixed [10].

Younger brother Alfred had a different career. He began his studies of archeology and art history in Bonn, continued his studies of law in Tübingen, and defended his doctoral dissertation in the field of economics in Berlin. There he also began an academic career within which his scientific contributions moved in a wide arc of social sciences over three periods. At the beginning of his career, he worked in Berlin and at the German University in Prague, and his scientific focus was in the domain of economics and the struggle for the division of the Czechia on ethnic grounds. After moving to Heidelberg, he completed his major work on the theory of the lowest cost of an industrial site [54], thus making a fundamental contribution to the development of economic geography. His theory

\footnotetext{
${ }^{27}$ Weber distinguishes four types: practical, theoretical, value, and formal

${ }^{28}$ It explains the positive influence of Protestantism and the negative influence of Catholicism, Confucianism and Hinduism.

${ }^{29}$ Officials have eight characteristics: freedom of decision; setting, not dealing; powers and duties; professionalism; commitment; professionalism; there is no heredity of position; written forms of communication.
} 
attempts to explain and predict the location pattern of the industry on a macro scale, based on minimal transportation and labor costs. The starting point of his theory is the location triangle with vertices that represent the main factors of production (market, sources of raw materials and production process). The problem is finding the optimal location of the factories where the two inputs (raw materials and workers) and output (market) meet. Weber showed that this location can be identified as a point where all transport costs are kept to a minimum (graphical representation of this point).

As a general rule, the optimal location will lie within the triangle or on one of its edges, but Weber also argued that in instances where some idiosyncratic locational advantage (e.g., a source of power or a pool of cheap labor) could be obtained, a site outside the triangle might sometimes be preferable to the transport-cost minimizing point [14].

His theory requires an analysis of agglomeration factors (leading to enterprise concentration), deagglomeration (leading to enterprise diversification) and regional factors (limiting companies to a certain geographical area), thus achieving Weber's point of optimal transport. Following this success, a new phase immediately begins through working together with brother Max to establish a new discipline, industrial sociology. After a decade of researching the position of industrial workers, he breaks up with Max, in which some historians see the influence of Else von Richthofen ${ }^{30}$. After Max's death, Alfred shifted the focus of his scientific work to the sociology of culture and published significant works ${ }^{31}$ in this field.

Weren't they both shaped by the historical school of German economics? Didn't they often cooperate in the Association for Social Policy? Did they not demand early the parliamentary organization of the German Empire? Weren't they solid liberals, albeit with distinctly national characteristics? Didn't both lead the path from economics to the sociology of culture? But if they agreed so in many respects, why did their works not reinforce each other? [46]

Despite the seemingly similar life paths and scientific contributions of the Weber brothers, their relevance in sociology is different. Alfred was one of the most prominent representatives of cultural sociology, and today he has almost completely disappeared from sociological discussions. He became primarily the subject of historians, who rightly saw him as an exceptional figure in recent German history, and of economic geographers, as evidenced by the fact that the Institute of Economics in Heidelberg bears his name. And what about Max's work today? Compared to Alfred, the situation is completely different with Max. His work is the subject of national and international sociological debate, especially with the emergence of neoliberal economics, when its topicality begins. It did not begin only in Germany "but became a trend in discussions of the methodological and theoretical foundations of historical sociology" [46].

\section{Park and Ullman: From Chicago to Seattle}

Unlike previous grand theories, which focus on large sections of history, modern theories of everyday life are a kind of opposite and relate to everyday life. They were created in

\footnotetext{
${ }^{30}$ Max's student who married economist Jaffa and then was in a relationship with both brothers

${ }^{31}$ Ideen zur Staats - und Kultursoziologie (1927), Kulturgeschichte als Kultursoziologie (1935), Farewell to European History or the Conquest of Nihilism (1947), Einführung in die Soziologie (1955).
} 
the 1920s and are the result of the work of sociologists who are connected to the creation of the famous Chicago school of sociology. The first generation of this school, under the strong influence of G. H. Mead [31], developed the theory of symbolic interactionism, and the most important representatives were: R. E. Park, E. Burgess, W. I. Thomas, R. D. McKenzie and others. The second generation of this school developed after 1945, combining symbolic interactionism with field research methods (today it is called ethnography), and the most important representatives were: H. Garfinkel, E. Goffman, G. C. Homans, J. S. Coleman and others.

Table 2: Overview of the most significant authors of contemporary theories of everyday life

\begin{tabular}{llll}
\hline Key thinkers & The theory is significant for explanation & Key concepts \\
\hline R. E. Park & Urban Ethnology & Fieldwork and Observation \\
\hline H. Garfinkel & $\begin{array}{l}\text { Achieving Everyday } \\
\text { Ethnomethodology }\end{array}$ & Goals & orplanatory Practices \\
\hline E. Gofman & Social Life as Dramaturgy & Distance to Role \\
\hline G. C. Homans & Theory of Exchange & Operant conditioning \\
\hline J. S. Coleman & Theory of Rational Choice & Opportunity Cost \\
\hline
\end{tabular}

This theory of symbolic interactionism, with all its varieties, focuses on the interaction of the acting individual and the symbols that have a particular meaning. The main determinants of this theory can be presented as: the action of people on things that have meaning; these meanings always arise through interaction with other people; people internationalize meanings, but also modify them through an interpretive process; people consciously use symbols; social interaction makes people more humane; people possess consciousness and self, ie. they are able to shape their actions and interactions; given the life situations they find themselves in, people choose goals [42]. Similarly, as in the previous chapter, not all modern theories of everyday life had an impact on the development of geographical thinking during its empirical - analytical phase, and for us the most interesting is urban ethnology founded by Park and Burgess in the 1920s. This theory left a strong influence on the development of social geography and conditioned the emergence of urban geography, which will reach its dynamic development only with the emergence of quantitative geography in the mid-1950s.

Robert Ezra Park (1864 - 1944) is considered the founder of ecological theory, which he developed within the famous Chicago school of sociology, and which achieved the greatest results in the period between the two world wars. At the beginning of his career, Park was engaged in journalism, and following the life of the city, he improved his observation techniques and field work, which helped him expand his interests in the domain of what would later become urban ethnography. He enrolled at Harvard (1898) relatively late ${ }^{32}$, but that did not stop him from making a brilliant academic career, which he began at a small university in Alabama (1905). In his 50th year, he came to the University of Chicago (1913-1934), where he achieved the greatest scientific results. Through his early three essays ${ }^{33}$, he tried to formulate a theory of social movements ${ }^{34}$,

\footnotetext{
${ }^{32} \mathrm{He}$ conducted his doctoral studies in Germany, listened to lectures by Mr. Simmel, and defended his PhD dissertation with prof. V. Vindelband in Berlin in 1904.

33 The City (1915), The Urban Community as a Spatial Pattern and a Moral Order (1926), and The City as a Social Laboratory (1929).

${ }^{34}$ It is a theory according to which immigration begins a "cycle of racial relations" between the majority and minority groups, and which goes through three phases: contact and competition; conflict and
} 
which was in fact the programmatic basis of the work of the Chicago School. He later (1925) and his collaborators expanded the first essay into the book The City ${ }^{35}$, which explained the development of the city as a model of concentric circles ${ }^{36}$.

This chart brings out clearly the main fact of expansion, namely, the tendency of each inner zone to extend its area by the invasion of the next outer zone. This aspect of expansion may be called succession, a process which has been studied in detail in plant ecology [38].

Park formed his views under the influence of George Simmel with an emphasis on the study of patterns in human behavior, to which he added elements of Herbert Spencer's social Darwinism [42]. Based on these theoretical assumptions, he built a model of society that could be compared to the ecological order, in which individuals cooperate, but also compete in the struggle for survival.

Park focused on four major social processes: competition, conflict, accommodation, and assimilation. While the latter three processes were cultural and often conscious, Park modeled the competitive process directly from biological ecologists and argued that it was "interaction without contact." He used plant communities reaching for a share of sunlight as analogous to the individuals striving for valued resources, often unaware of others who were similarly striving and limiting the availability of those resources [41].

The first group of researchers at the Chicago School dealt with comprehensive schemes of social change and social planning, and they were critical of the government 's superficial measures to alleviate the economic crisis [22]. The greatest contribution to this, in addition to the Park, was made by: W. I. Thomas (sharp critiques of social work), F. Znaniecki (introduce terms such as humanistic coefficient and culturalism) and E. V. Burgess (cognitive maps of unplanned patterns of city growth). It was this team that became most responsible for the rise of the Chicago School of Sociology, which will deal with the detailed processing of data on urban communities. The result of this group's work is the establishment of a field station of the Department of Sociology on the outskirts of Chicago, with the task of improving life in the poor neighborhood. As a result, the concepts of citizen participation, self-help, and the culture of poverty have emerged that will become key ideas in the war on poverty. Park's contribution to social theory is reflected in the recognition of "dominant processes of cooperation and competition within the socio-ecological environment" [41]. The first process is characterized by two basic forms (urbanization and institutions), where urbanization and advanced division of labor create interdependent economic dependence. On the other hand, institutions, from the family to the press, help to integrate actors into a common moral and symbolic order. As for social competition, Park felt that it focuses on the struggle for "domination", which can occur at different levels (an individual competes with others for employment, urban neighborhoods aspire to become centers of social power, etc.). According to the Park,

adjustment; probable assimilation of a minority group. This theory was later rejected, because immigrants maintained the culture of their ancestors in the following generations as well.

${ }^{35}$ Park wrote 6 chapters, Burgess two, and McKenzie and Wirth each

${ }^{36}$ Commuter zone, Residential zone, Working class zone, Zone of transition, Factory zone, The Loop or Central Business District (CBD). 
cooperative and competitive social processes often take place in repetitive patterns of "succession," and his best-known example is the study of population patterns in Chicago (immigrants regularly move from urban centers to the periphery to establish safer strongholds in their new country). His most prolific method of social research became social mapping, which was subsequently adopted by urban geographers with the aim of studying the spatial distribution and functional relationships between demographic and settlement factors. Despite these successful solutions and the connection between social theory and urban geography, the Chicago School has also been the subject of scientific criticism:

Critiques of the Chicago School emerged shortly after as other urban scholars found the theory did not match up well to research in other landscapes. The Chicago School has also been criticized theoretically, most notably by scholars who did not believe the ecological analogy compared significantly with urban human social relations (see a discussion of Firey 1945, 1947; Sjoberg 1960 and Harvey 1973 in Valentine 2001). Although widely critiqued, the Chicago School opened up discussions and theorizations of "community" and promoted research into neighborhoods for subsequent geographers and other urban scholars [11].

Edward Louis Ullman (1912-1976) was a brilliant geographical mind, who achieved significant scientific results in various fields of geography (urban, traffic, regional planning), but also in the field of public administration (traffic, trade, planning), international organizations (OECD) and the military (responsible duties during WW II). He received his academic education at several American universities, and achieved full affirmation at the University of Washington and as a visiting professor ${ }^{37}$ around the world [19]. Together with W. Garrison, he is credited with applying quantitative methods and that through a series of strategies and practices he educated an extremely talented and influential group of geographers ${ }^{38}$ who stimulated others to adopt the concept of "new geography" [35]. In addition, it is interesting for us because of its contribution to the development of urban geography and its theoretical improvement. Very important is the work A Theory of Location for Cities (1941), which he published in a sociological journal due to the closeness of the subject of the paper. In it, he analyzed Christaller's theory of central places ${ }^{39}$, which is better suited to agrarian than industrial regions, and argued that because of this:

It is not static but changes to fit changes in underlying conditions, particularly transportation. The system also varies from place to place in the world in line with population density, type of agriculture, governmental organization, and many other factors. These underlying regional differences make possible comparisons between central-place systems in the United States [49].

After this, he continued elaboration and description different urban forms, thus improving the previous models ("concentric circles" and "sector forms"). His capital contribution to urban geography was the "multiple core model", which he developed together with C.

\footnotetext{
${ }^{37}$ Rome, Vienna, Moscow, London, Jerusalem

${ }^{38}$ B. Berry, R. Boice, W. Bunge, M. Dacei, A. Getis, D, Marble, R. Morrill, J. Nistuen, F. Pitts and V. Tobler

${ }^{39}$ Based on housing density and city size of southern Bavaria.
} 
Harris [20]. Their model is based on the description of Chicago and starts from the assumption that people are using cars more and more, the city land is not monotonous and that there is no even distribution: resources, inhabitants and transportation costs. Due to that, secondary nodes are formed in other parts of the city (due to the reduction of daily trips), which act as growth points and over time take on the functions of secondary CBD (central business district). That is why he called this concept the model of multiple cores, which was criticized for its Darwinist (evolutionary) and ecological basis (too simplified patterns of urban land use). Their ideas influenced thinking about the structure of the modern city and, with the increasing importance of spatial analysis, aroused the second generation of urban theorists in the 1960s and 1970s [15]. The key principle in this Harris - Ullman model was transport costs, because it expressed the importance of distance in the decision - making process. Among other factors, which influenced production, this one was predominantly geographical and was adopted by Ullman's followers. Therefore, he considered that "the amount of movement between two places was related to three factors: complementarity, intervening opportunity, and transferability" [24].

This model could be linked to the process of spatial interaction, which represents a dynamic process of flow from one location to another. It is a general concept that can refer to the movement of people, such as suburban travel or intercontinental migrants, but it can also refer to the trade of goods such as raw materials or to the flows of intangible roles such as information [30]. Spatial differentiation emerged as a result of transport and trade, enabling specialization in certain economic activities and the concentration of different social groups. Also, the root of this model is in the term La géographie de la circulation ${ }^{40}$, by French geographers from the beginning of the 20th century.

\section{CONCLUSION}

In the middle of the 19th century begins the process of establishing new social relations (feudalism - capitalism), which in the domain of theoretical understanding of the new age (modern) is recognized through the strengthening of social sciences (sociology, psychology, geography) and weakening the influence of philosophy on these processes. This is confirmed by social theory, which during the empirical-analytical phase of geography had a decisive influence on the formation of its theoretical-methodological framework. This was shown through a comparative presentation of the main achievements of leading sociologists and geographers within the then leading national schools (French, German, American), which is visible in its domain: paradigmatic orientation (exploration, determinism, regionalism, spatial science); theoretical framework (possibilism, chorologism, exceptionalism, logic positivism) and disciplinary differences (anthropogeography, regional, cultural and quantitative geography). Undoubtedly, social theory, through grand theories and theories of modern life, managed to impose itself on geography as a new theoretical framework, which replaced the hitherto dominant philosophical discourse.

\footnotetext{
${ }^{40}$ The term was also used by Robert Capot-Rey (1897-1977), who studied the characteristics of the nomadic tribes of North Africa.
} 


\section{REFERENCES}

[1] Andrews, H. F. The Durkheimian and Human Geography: Some Contextural Problems in the Sociology of Knowledge, Transactions of the Institute of British Geographers, UK, vol. 9 (3), pp 315-336, 1984.

[2] Agnew, J. A. The devaluation of place in social science, The Power of Place: Bringing Together Geographical and Sociological imaginations, US, pp 9-29, 1989.

[3] Bennett, D. Positivism / Positivist Geography. International Encyclopedia of Human Geography, UK, vol. 8, pp 295-311, 2009.

[4] Barnes, T. J. Quantitative Revolution, International Encyclopedia of Human Geography, UK, vol. 9, pp 33-38, 2009.

[5] Berdoulay, V. Place, meaning, and discourse in French language geography. The Power of place: Bringing together Geographical and Sociological imaginations, US, pp 124-139, 2014.

[6] Cosgrove, D. Ruskin's European visions, Geography and Vision: Seeing, Imagining and Representing the World, UK, pp 135-152, 1984.

[7] Cloke, P, Philo, C \& Sadler, D. Introduction: Changing Approaches to Human Geography, Approaching Human Geography, UK, pp 1-27, 1991.

[8] Durkheim, E. Emile Durkheim's Life and Works: Timeline 1858-1917, The Division of Labor in Society, Yugoslavia, pp 47-51, 1972.

[9] Eckersley, R. The Failed Promise of Critical Theory, Environmentalism and Political Theory, UK, pp 97-117, 1992.

[10] Elden, S. Territory - Part I, The Wiley-Blackwell Companion to Human Geography, UK, pp 260-270, 2011.

[11] England, M. Community. A Companion of Social geography, UK, pp 152-174. 2011.

[12] Dodgshon, R. A. Hierarchies in Society and Space: Reflections on their Orogenesis, European past: social evolution and spatial order, UK, pp 88-129, 1987.

[13] Kong, L. Religious Landscapes. A Companion to Cultural Geography, US, pp 365-381, 2004.

[14] Benko, G. \& Scott, A. J. Economic geography: tradition and turbulence, Human Geography: A History for the Twenty First Century, UK, pp 1-24, 2004.

[15] Gold, J. R. Modern City. International Encyclopedia of Human Geography, UK, vol. 7, pp 150-156, 2009.

[16] Gregory, D. Geography and the world-as-exhibition, Geographical imaginations, US, pp 1569, 1994.

[17] Habermas, J. The Idea of the Theory of Knowledge as Social Theory. Knowledge and Human Interests, Yugoslavia, pp 74-98, 1975.

[18] Habermas, J. Hegel's notion of modernity, The Philosophical Discourse of Modernity: Twelve Lectures, Yugoslavia, pp 27-51, 1988.

[19] Harris, C. D. Edward Louis Ullman 1912-1976, Annals of the Association of American Geographers, US, vol. 67 (4), pp 595-600, 1977.

[20] Harris, C. D. \& Ullman, E. L. The nature of cities. Annals of the American Academy of Political and Social Science, US, vol. 242, pp 7-17, 1945.

[21] Hartshorne, R. The Justification of the Historical concept of Geography as a Chorographic science, Perspective on the Nature of Geography, US, pp 130-148, 1959.

[22] Janowitz, M. Introduction, The City, US, pp vii-x, 1984. 
[23] Johnston, R. J. Foundations. Geography and Geographers: Anglo American Human Geography Since 1945. UK, pp 38-52, 1997.

[24] Johnston, R. J. Growth of systematic studies and the adoption of "scientific method". Geography and Geographers: Anglo American Human Geography Since 1945. UK, pp 53-101, 1997.

[25] Kitchin, R. Positivistic Geographies and the Spatial Science, Approaches to Human Geography, UK, pp 23-34, 2006.

[26] Leach, E. R. The comparative method in anthropology, International Encyclopedia of the Social sciences, US, vol. 1, pp 339-345, 1968.

[27] Philo, C. \& Söderström, O. Social geography: looking for society in its spaces, Human Geography: A History for the Twenty First Century, UK, pp 120-153, 2004.

[28] Lossau, J. Anthropogeography (after Ratzel). The International Encyclopedia of Human Geography, UK, vol. 1, pp 140-146, 2009.

[29] Livingstone, D. N. The Geographical Tradition: A Conversational conclusion. The Geographical Tradition, UK, pp 347-358, 1992.

[30] MacLahlan, I. Spatial interactions. Encyclopedia of World Geography, US, pp 889-890, 2005.

[31] Mead, G. H. The Point of View of Social Behaviorism, Mind, Self, and Society, Croatia, pp 1-41, 2003.

[32] Mills, S. R. Abstracted Empiricism, The Sociological Imagination, Serbia, pp 50-75, 1998.

[33] Mutabdzija, G. Paradigms in Regional Geography, Regional geography of Europe, US, pp 18-26, 2018.

[34] Mutabdzija, G. Crown stone, Geophilosophy of the premodern. US, pp 46-49, 2021.

[35] O'Kelly, M. E. Spatial interaction models, International Encyclopedia of Human Geography, UK, vol. 10, pp 365-368, 2009.

[36] Oakes, T. S. \& Price, P. L. The Physiogamy of France: Paul Vidal de la Blache, The Cultural Geography Reader, UK, pp 90-95, 2008.

[37] Panelli, R. (). Social geography. International Encyclopedia of Human Geography, UK, vol. 10, pp 185-194, 2009.

[38] Park, R. E., Burgess, W. E. \& McKenzie, R. D. The Growth of the City, The City, US, pp 47-62, 1984.

[39] Peet, R. The social origin of environmental determinism. Annals of the Association of American Geographers, US, 75 (3), pp 309-333, 1985.

[40] Ratzel, F. The Territorial Growth of States. Scottish Geographical Magazine, UK, vol. 12, pp 351-361, 1896.

[41] Ritzer, G. Ecological theory, Encyclopedia of Social theory I - II, US, pp 227-233, 2005.

[42] Ritzer, G. Robert Park, Encyclopedia of Social theory I - II, US, pp 547-550, 2005.

[43] Ritzer, G. Classic Theory I, Contemporary Sociological Theory and its Classic Roots, Serbia, pp 49-88, 2009.

[44] Ruppert, K., Schaffer, F. \& Mater, J \& Paesler, R. Developmental lines of anthropogeography and spatially oriented sociological research, Sozialgeographie, Yugoslavia, pp 11-19, 1981.

[45] Sauer, C. Cultural geography (1931), Carl Sauer on Culture and Landscape Readings and Commentaries, US, pp. 136-143, 2009. 
[46] Schluchter, W. Max und Alfred Weber - zwei ungleiche Brüder. Ruperto Carola, Germany, vol. 3, pp 29-35, 1994.

[47] Taylor, P. J. The value of a geographic perspective, The Future of Geography, UK, pp 92110, 1985.

[48] Taylor, P. J. \& Wuste, v.d. H. Political geography: spaces between war and peace. Human Geography: A History for the Twenty First Century, UK, pp 83-104, 2004.

[49] Ullman, E. L. A theory of location for cities, American Journal of Sociology, US, vol. 46 (6), pp 853-864, 1941.

[50] Unwin, T. Science, knowledge and interest, The Place of Geography. UK, pp 30-44, 1992.

[51] Vidal, P. d. 1. B. Introduction: Meaning and Aim of Human geography, Principles of Human Geography. UK, pp 3-26, 1965.

[52] Zeldin, T. Attitudes to Foreigners, France 1848-1945: Ambition, Love and Politics, UK, vol. 1, pp 86-139, 1973.

[53] Weber, M. The Issue, The Protestant Ethic and the Spirit of Capitalism, Yugoslavia, pp 569, 1989.

[54] Friedrich, C. J. Alfred Weber's Theory of the location of industries, US, pp 17-36, 1929.

[55] Werlen, B. Everyday Regionalization's. International Encyclopedia of Human Geography, UK, vol. 9, pp 286-293, 2009.

[56] West, R. C. Alfred Hettner (1859-1941), Pioneers of Modern Geography, US, pp 77-106, 1990. 